\title{
Interference by Oxygen in the Acetylene-reduction Test for Aerobic Nitrogen-fixing Bacteria
}

\author{
By J. DROZD AND J. R. POSTGATE \\ A.R.C. Unit of Nitrogen Fixation, University of Sussex, Brighton, Sussex, BNI $9 Q J$ \\ (Accepted for publication 25 November 1969)
}

The reduction of acetylene (Dilworth, I966; Schöllhorn \& Burris, 1967) with the detection of ethylene by gas-liquid chromatography is a widely used method of assaying nitrogen fixation (Stewart, Fitzgerald \& Burris, 1967; Hardy, Holsten, Jackson \& Burns, 1968). Nitrogen fixation by the Azotobacteriaceae, which are important aerobic nitrogen-fixing bacteria in nature, can be inhibited by oxygen, particularly in carbon- or phosphate-limiting conditions (Dalton \& Postgate, I969a). We now report that the oxygen sensitivity of Azotobacteriaceae can lead to false assessments of nitrogenase activity by the acetylene-reduction test.

Batch cultures of Azotobacter chroococcum (NCIB 8003), A. vinelandii (NCIB 8660) and $A$. macrocytogenes (NCIB 8700) were grown in Burk's sucrose medium (Newton, Wilson \& Burris, I953) and $2 \mathrm{ml}$. samples of growing cultures were shaken at 75 strokes/ min. at $30^{\circ}$ in $25 \mathrm{ml}$. flasks under atmospheres of $\mathrm{A}+\mathrm{O}_{2}+\mathrm{C}_{2} \mathrm{H}_{2}$; the latter always at $0.03 \mathrm{~atm}$. Maximum rates of acetylene reduction usually occurred at $p \mathrm{O}_{2}$ values well below atmospheric (Fig. I A). Comparable bell-shaped curves relating acetylene reduction to $p \mathrm{O}_{2}$ in the aerobic nitrogen-fixing bacteria $A$. chroococcum (Dalton \& Postgate, I $969 b$ ) and Mycobacterium flavum (Biggins \& Postgate, 1969) and the bluegreen alga Anabaena flos-aquae (Stewart, 1969) have been reported earlier. The optimal $p \mathrm{O}_{2}$ for each species depended on the population density; only with very dense cultures (e.g. A. vinelandii at $2 \mathrm{mg}$. dry wt $/ \mathrm{ml}$.) was the optimal $p \mathrm{O}_{2}$ for acetylene reduction at or above the atmospheric value.

Shaking samples of the cultures in air on a Griffin flask shaker (Griffin \& George, Wembley, England) at $250 \mathrm{vib}$./min. for 2 to $4 \mathrm{~min}$. before testing normally lowered their maximum acetylene-reducing activity by 25 to $75 \%$; only dense cultures with optimum $\mathrm{pO}_{2}$ values at or above 0.2 atm. were unaffected by such shaking. The 'switching off' of acetylene-reducing activity in sensitive cultures could be reversed: gentle shaking (75 strokes/min.) at $\mathrm{pO}_{2} \mathrm{O}^{-2} \mathrm{~atm}$. for $10 \mathrm{~min}$. restored the original activity tested at the optimum $\mathrm{pO}_{2}$. However, prolonged shaking in air (up to $\mathrm{I} \mathrm{hr}$ ) caused irreversible loss of up to $60 \%$ of the original activity.

It is possible to 'adapt' populations to high oxygen tension (Fig. I B). Nitrogenfixing continuous cultures of Azotobacter chroococcum were set up at $30^{\circ}$ as described by Dalton \& Postgate (I969b), and 'adapted' to 0.09 and 0.55 atm. $\mathrm{O}_{2}$ at $\mathrm{D}=$ $0.2 \mathrm{hr}^{-1}$; oxygen electrode measurements showed the ambient oxygen concentration in both cultures to be about I $2 \mu \mathrm{M}$ and the population densities were the same. The respiratory activities of such populations were related directly to $p \mathrm{O}_{2}$ : at $p \mathrm{O}_{2} 0.55$ the $Q \mathrm{O}_{2}$ was about $2700 \mu \mathrm{l} . / \mathrm{mg}$. dry wt/hr; at $p \mathrm{O}_{2} 0.09$ it was 1400 . The low-oxygen population, like a batch culture, was readily 'switched off' by vigorous shaking in air. 
The high $p \mathrm{O}_{2}$ population was not; it even tolerated shaking in pure $\mathrm{O}_{2}$, a treatment which caused irreversible suppression of acetylene-reducing activity of the low $\mathrm{pO}_{2}$ population.

The populations so far discussed were all ' $\mathrm{N}_{2}$-limited' in the sense used by Dalton $\&$ Postgate $(1969 b)$. Carbon-limited populations are very sensitive to oxygen inhibition of growth; so, to test organisms of a different nutritional status, a carbon-limited continuous culture of Azotobacter chroococcum growing in air was studied. Its $p \mathrm{O}_{2}$

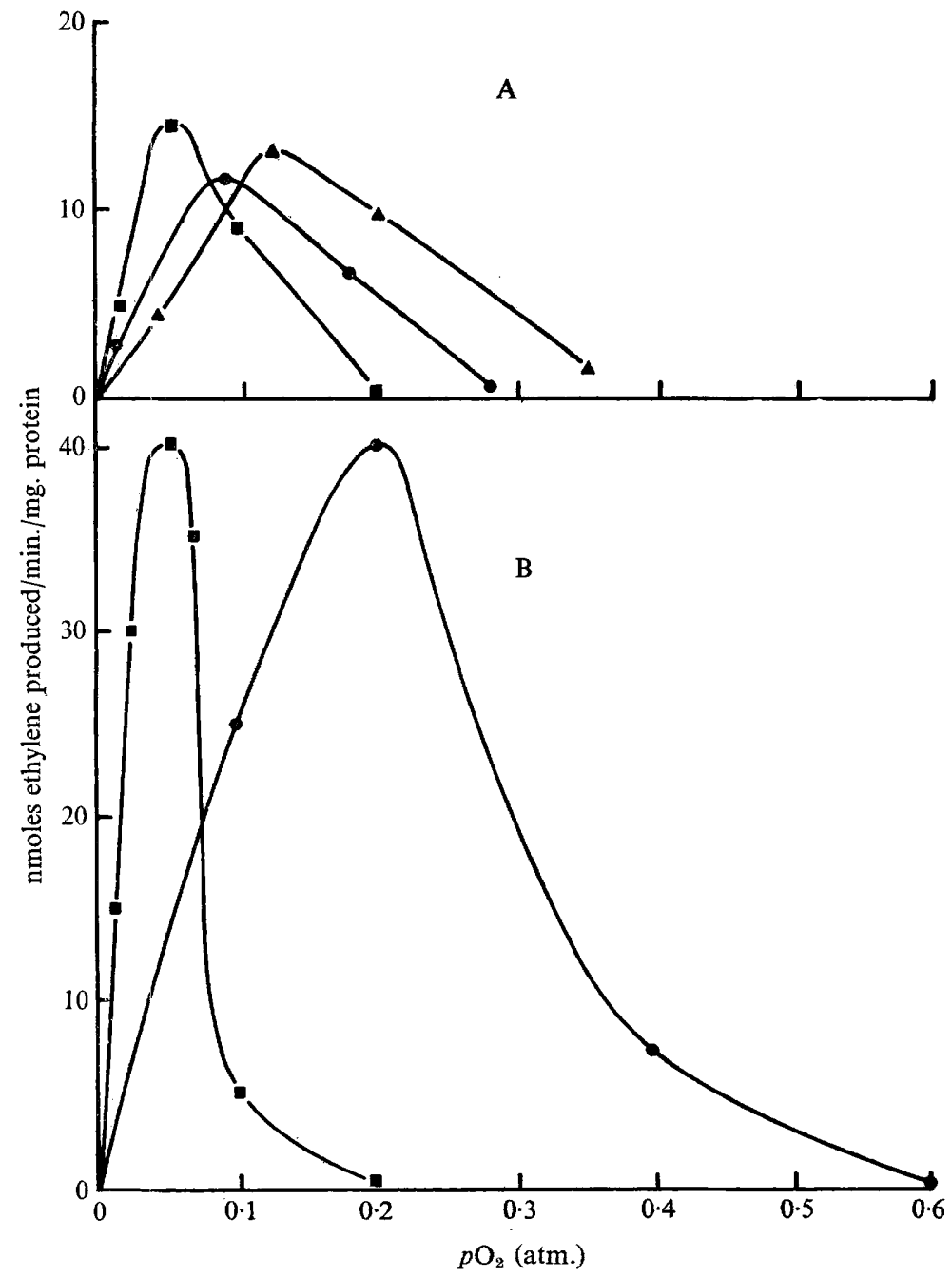

Fig. I. (A). Effect of $p \mathrm{O}_{2}$ on acetylene reduction by azotobacters. $2 \mathrm{ml}$. samples of batch cultures of: $-\longrightarrow, A$. chroococcum; $\Delta-\mathbf{\Lambda}, A$. macrocytogenes; $\square-\boldsymbol{A}$. vinelandii; tested at 75 strokes $\mathrm{min}, 30^{\circ}$ under argon + oxygen + acetylene, the latter always at $0.03 \mathrm{~atm}$. (B). Effect of $p \mathrm{O}_{2}$ during growth, and respiratory activity, on the optimum $p \mathrm{O}_{2}$ for acetylene reduction by $A$. chroococcum. I $\mathrm{ml}$. samples containing $0.5 \mathrm{mg}$. dry wt organisms from continuous culture at $\mathrm{D}=0.2 \mathrm{hr}^{-1}$ tested at 150 strokes $/ \mathrm{min}$. -0 , culture grown at $p \mathrm{O}_{2}=0.55 \mathrm{~atm}, Q \mathrm{O}_{2}=2700 \mu \mathrm{l} . / \mathrm{mg}$. dry wt $/ \mathrm{hr} ; \mathbf{\square}$, culture grown at $p \mathrm{O}_{2}=0.09 \mathrm{~atm}$, $Q \mathrm{O}_{2}=\mathrm{I} 400 \mu \mathrm{l} . / \mathrm{mg}$. dry wt $/ \mathrm{hr}$. 
optimum for acetylene reduction was 0.025 atm. and no activity at all was detected a $0.2 \mathrm{~atm}$. Shaking populations comparable to the $\mathrm{N}_{2}$-limited ones on a vortex mixer in air for I min. lowered activity at the optimum $\mathrm{pO}_{2}$ by $50 \%$.

The present work shows three points relevant to the routine use of the acetylenereduction test. (i) Aerobic bacteria rarely show their optimal activity at the atmospheric $p \mathrm{O}_{2}$ value; (ii) aerobic bacteria can undergo, partially or completely, a reversible 'switching off' process when vigorously aerated by shaking; (iii) the sensitivity to 'switching off' depends on population density and nutritional status.

Field samples are usually tested at the atmospheric $p \mathrm{O}_{2}$ of $0 \cdot 2$, which is reasonable because, even if the oxygen inhibits some of the bacteria present, this condition fairly represents their natural state. Soil and water organisms are likely to be growing under carbon-limited conditions and adapted to sub-atmospheric $\mathrm{pO}_{2}$ values; conditions which may be expected to maximize oxygen damage on handling. Therefore, if natural samples are vigorously shaken in air or otherwise unduly oxygenated, it is likely that aerobic nitrogen-fixing bacteria will partly or wholly 'switch off' their nitrogenase systems and the test will give a falsely low estimate of the original nitrogenase activity. The nature of the 'switch-off' and inhibition processes will be discussed in more detail elsewhere; we present the above data because of their relevance to the general use of the acetylene-reduction test.

\section{REFERENCES}

Biggins, D. \& Postgate, J. R. (1969). Nitrogen fixation by cultures and cell-free extracts of $M y c o$ bacterium flavum 301. Journal of General Microbiology 56, 181.

Dalton, H. \& Postgate, J. R. (1969a). Effect of oxygen on growth of Azotobacter chroococcum in batch and continuous cultures. Journal of General Microbiology 54, 463.

Dalton, H. \& Postgate, J. R. (1969b). Growth and physiology of Azotobacter chroococcum in continuous culture. Journal of General Microbiology 56, 307.

Dilworth, M.J. (1966). Acetylene reduction by nitrogen-fixing preparations from Clostridium pasteurianum. Biochimica et Biophysica Acta r27, 285 .

Hardy. R. W. F., Holsten, R. D., Jackson, E. K. \& Burns, R. C. (1968). The acetylene-ethylene assay for $\mathrm{N}_{2}$ fixation: laboratory and field evaluation. Plant Physiology 43, 1185.

Newton, J. W., Wilson, P. W. \& Burris, R. H. (I953). Direct demonstration of ammonia as an intermediate in nitrogen fixation by Azotobacter. Journal of Biological Chemistry 204, 445.

Schöllhorn, R. \& Burris, R. H. (I967). Acetylene as a competitive inhibitor of $\mathrm{N}_{2}$ fixation. Proceedings of the National Academy of Sciences of the United States of America 58, 213.

StewART, W. D. P. (1969). Nitrogen fixation by free-living micro-organisms. Proceedings of the Royal Society B I72, 367.

Stewart, W. D. P., Fitzgerald, G. P. \& Burris, R. H. (1967). In situ studies on $\mathrm{N}_{2}$ fixation using the acetylene reduction technique. Proceedings of the National Academy of Sciences of the United States of America 58, 207 I. 